IRA-INTERNATIONAL JOURNAL OF MANAGEMENT \& SOCIAL SCIENCES

(A scholarly peer reviewed and refereed publication of Institute of Research Advances)

ISSN 2455-2267 Vol.02, Issue 03 (March 2016)

DOI: https://dx.doi.org/10.21013/jmss.v2.n3.pl

\title{
Determinants of Profitability of Indian Public Sector Banks
}

\author{
Naresh Kedia \\ Asst. Professor \\ Amity University, Gwalior, India.
}

\begin{abstract}
$\underline{\text { Abstract: }}$
In this study, we have analyzed the determinants of profitability of Indian Public Sector Banks which reveals four independent variables that affect the net profit: Nonperforming assets, Credit Deposit Ratio, Net Interest Income and Operating Expenses. We have used the Multiple Regression Model for its analysis. We found out that, only two of these independent variables i.e. Credit Deposit Ratio and Net Interest Income affect the net profitability of Indian Public Sector Banks in a major way.
\end{abstract}

Keywords: Non-performing assets, credit deposit ratio, net interest income, net profitability, multiple regressions

JEL Classification: G2, G21, G210

\section{Introduction:}

Banking sector in India is broadly classified into three categories namely Public Sector Banks which include Nationalized Banks and SBI and associates, Private Sector Banks which includes Old Private Sector Banks and New Private Sector Banks and Foreign Banks. Apart from these almost 80 regional rural banks is also operating in India. The central bank of the country i.e. RBI monitors the decripencies and shortcoming in the system. The first banks were Bank of Hindustan (1770-1829) and The General Bank of India, established 1786. State Bank of India is the largest bank and the oldest still in existence. . The nationalization of India started in 1969 and all major banks were nationalized and from thereon it has remained in their ownership only. They are run under a structure know as 'profit-making public sector undertaking' (PSU) and are allowed to compete and operate as commercial banks. After liberalization in 1990s new private commercial banks and a number of foreign banks enter in to Indian banking sector. This era called new generation banking. 
In modern era, every bank and banking group is striving to attract more and more customers towards it, so they can make its name in the banking industry and gets fame by their working and operations so that their customers' loyalty can be increased towards them and they are able to utilize this in their future policies. Competition among them has also make them quality oriented. Now a day, they haven't only concerned about providing their customers with lots of facilities but the quality of those services are also their major concern issue. The only segment which is mostly benefitted from these activities and operations of the banks are the customers. Today banking industry is not the bank oriented but it is customer oriented. All the banks and banking groups are doing what their customers are demanding from them. They are ready to provide them all the facilities only to retain them with their bank. Some of the examples of this are 24 hour ATM facility to their customers, mobile banking, tele-banking, electronic fund transfer etc. Thus these facilities make customers more contended and satisfied.

There are different parameters on which these banks and bank groups compete with each other. The major purpose behind this competition is to improve their customer base and profitability by increasing their efficiency. So the parameter hold the important place in the policies of the banks and they should be properly handled and appropriate polices should be made to make the best use of these parameters.

An accounting concept which shows the excess of income over expenditure viewed during a specified period of time is called PROFIT and has remained the major reason for there existence. On the other hand, the Term profitability is a relative measure where profit is expressed as a ratio, as a percentage. The relationship of the absolute amount of profit with various other factors is depicted by profitability. There are number of exogenous and endogenous factors affecting profitabiliuty of the banks. The factors like changes in monetary policy quantitative credit control like changes in statutory liquidity ratio, cash reserve ratio, manipulation of bank rates, qualitative credit controls like selective credit control measures, credit deposit ratio, changes in interest rates on advances and deposits, region-wise guidelines on lending to priority sector, levy of tax on interest income etc.are exogenous $\mathrm{n}$ nature.Various other factors like timely recovery of loans, careful control of expenditure are endogenous.

In practice executives define profits in banks as the difference between total earnings from all earning assets and total expenditure on managing entire asset liabilities portfolio. In case of banks, the main source of income is interest earned and discount on bills discounted. The difference between the interest earned on loans and interst paid on depotst actually represents the bank efficiency.

\section{New Generation Banking}

The liberalize policy (1990)of Government of India permitted entry to private sector in the banking and the industry has witnessed the entry of new generation private banks. The major different parameters that are distinguishing these banks from all the other banks in the Indian banking are the level of service that is offered to the customer. Verified the focus 
has been centered on the customer - understanding his needs and preempting him and consequently delighting him with various configurations of benefits and a wide portfolio of products and services.

Most of the banks in this category are concentrated in the high-growth urban areas in metros (that account for approximately $70 \%$ of the total banking business). With the efficiency of the major focus, these banks has leverage on their strengths and competencies viz. operational efficiency and flexibility, Management, superior product positioning and higher employee productivity skills.

At present era Indian banking sector is very wide and playing a prominent role in India's service sector. The services sector is playing a very vital role in the Indian economy. The sector accounting for 60 per cent of the gross domestic product (GDP), grew 5 per cent in the FYl3.

\begin{tabular}{|l|c|}
\hline Types of Bank & 2012-13 \\
\hline State Bank of India \& Associates Banks & 08 \\
\hline Nationalized Banks & 21 \\
\hline Private Sector Banks & 18 \\
\hline Foreign Banks & 32 \\
\hline Regional Rural Banks & 80 \\
\hline
\end{tabular}

(Source: rbi.org.in)

\section{Current Scenario of Banking Sector in India:}

India's Rs 77 trillion (US\$ 1.25 trillion)-banking industry is the backbone to the economy and is expected to reach US $\$ 28.5$ trillion by 2025 . Increase in working population and growing disposable incomes will increase the demand for banking and related services. Personal finance and Housing are expected to remain key demand drivers. India's banking sector is on a high-growth trajectory with around the 3.5 ATMs and less than 7 bank branches per 100,000 people according to the World Bank report. The statistics are going to improve in future as the Government aims to have maximum financial inclusion in the country. The Policymakers are making all the efforts to provide a facilitating policy framework and infrastructure support to ensure meaningful financial inclusion. Apart from this, financial institutions are collaborating with other service providers (in the fields of technology, telecom and consumer product providers) to create an enabling environment. Indian banks currently devote around 15 per cent of total spending on the technology. Public sector banks account for over 73 per cent of interest income in the sector. A deposit has grown at a compound annual growth rate (CAGR) of 21.2 per cent during FY06-13; in FY13 total deposits stood at US\$1,274.3 billion. Mobile, Internet banking and extension of facilities at ATM stations are expected to improve operational efficiency. Total number of ATMs in India has increased to 104,500 in 2012 and is further expected to double over the next two years 


\section{Key Statistics:}

According to the Central Bank of India i.e RBI'Quarterly Statistics on Deposits and Credit of Scheduled Commercial Banks', March 2013, 52.4 per cent was accounted to nationalized banks of the aggregate deposits, and 22 percent was accounted by the State Bank of India (SBI) and its Associates. The share of New Private Sector Banks, Old Private Sector Banks, Foreign Banks, and in aggregate deposits was 13.6 per cent, 5.1 per cent, 4 per cent and 2.9 per cent, respectively. Nationalized Banks accounted for the highest share of 51 per cent in gross bank credit followed by State Bank of India and its Associates (22.7 per cent) and New Private Sector Banks (14\%). Foreign Banks, Old Private Sector Banks and Regional Rural Banks had shares of around 4.9 per cent, 5 per cent and 2.5 per cent, respectively.

\section{Government \&\& RBI Initiative:}

The RBI on 7 Nov. 2013 allowed wholly-owned subsidiary (WOS) of foreign banks to acquire domestic private banks as well as set up branches anywhere in the country. ITheir listing on the local stock exchange in also allowed. However, foreign bank subsidiary will not be allowed to hold more than 74 per cent. (Source: Business Today) The indea of financial inclusion have firther encouragec by RBI by giving conditional freedom to open beanches in tier I cities without seeking the central banks approval in each case.(www.ibef.org)

\section{$\underline{\text { Road Ahead }}$}

The Indian banks has become more competitive and pro-active by adopting new techniques like internet and mobile to provide their service. Rs 41,700 corer (US\$ 6.78 billion) on IT products and services in 2013, have been projected to be spend which is 13 percent more then last year i.e. 2012. The spending will be on internal IT services (including personnel), data centre technologies, software and devices and telecom services. (Source: Study by research and analyst firm Gartner)

By 2020 it is expected that Indian banking system will become the fifth largest in the world. The report says that India is one of the top 10 economies of the world with a relatively lower domestic credit to gross domestic product (GDP) percentage, their lies a huge scope of growth for the banking sector. It is expected that the banking industry will grow at a compounded annual growth rate (CAGR) of 17 per cent in the medium term, eventually leading to higher credit penetration in the economy

(Source: Report by KPMG prepared in association with the Confederation of Indian Industry) 


\begin{tabular}{|c|c|c|c|c|c|}
\hline \multirow[t]{2}{*}{$\begin{array}{l}\text { Sr. } \\
\text { No }\end{array}$} & \multirow[t]{2}{*}{ Item } & \multicolumn{2}{|c|}{$\begin{array}{l}\text { Amount Outstanding } \\
\text { (As at end-March) }\end{array}$} & \multicolumn{2}{|c|}{ Percentage Variation } \\
\hline & & 2012 & 2013 & $2011-12$ & $2012-13$ \\
\hline 1 & $\begin{array}{ll}\text { Balance } & \text { Sheet } \\
\text { Operations } & \end{array}$ & & & & \\
\hline 1.1 & Total liabilities/assets & 83209 & 95733 & 15.8 & 15.1 \\
\hline 1.2 & Deposits & 64535 & 74295 & 14.9 & 15.1 \\
\hline 1.3 & Borrowings & 8438 & 10105 & 24.9 & 19.8 \\
\hline 1.4 & Loans and Advances & 50736 & 58797 & 18.1 & 15.9 \\
\hline 2 & Profitability & & & & \\
\hline 2.1 & Net Profit & 817 & 912 & 16.1 & 11.6 \\
\hline 2.2 & ROA (\%) & 1.08 & 1.03 & - & - \\
\hline 2.3 & \begin{tabular}{|l|} 
ROE (\%) \\
\end{tabular} & 14.60 & 13.84 & 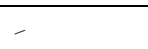 & 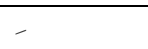 \\
\hline 2.4 & NIM (\%) & 2.9 & 2.8 & - & - \\
\hline 3 & Asset Quality & & & & \\
\hline 3.1 & Gross NPAs & 1429 & 1940 & 46.0 & 35.8 \\
\hline 3.2 & Net NPAs & 652 & 986 & 56.4 & 51.2 \\
\hline 4 & $\begin{array}{l}\text { Sectoral Deployment of } \\
\text { Bank Credit }\end{array}$ & & & & \\
\hline 4.1 & Gross Bank Credit & 43714 & 49642 & 17.1 & 13.6 \\
\hline 4.2 & Agriculture & 5484 & 5899 & 14.1 & 7.6 \\
\hline 4.3 & Industry & 19374 & 22302 & 20.7 & 15.1 \\
\hline 4.4 & Services & 10166 & 11486 & 14.5 & 13.0 \\
\hline 4.5 & Personal Loans & 7873 & 9009 & 13.4 & 14.4 \\
\hline 5 & $\begin{array}{l}\text { Technological } \\
\text { Development }\end{array}$ & & & & \\
\hline 5.1 & $\begin{array}{l}\text { Total number of credit } \\
\text { cards (in millions) }\end{array}$ & 18 & 20 & -2.2 & 10.2 \\
\hline 5.2 & $\begin{array}{l}\text { Total number of debit } \\
\text { cards (in millions) }\end{array}$ & 78 & 331 & 22.1 & 19.0 \\
\hline 5.3 & Number of ATMs & 95686 & 114014 & 28.4 & 19.2 \\
\hline 6 & Financial Inclusion & & & & \\
\hline 6.1 & $\begin{array}{l}\text { Credit-deposit ratio (Per } \\
\text { cent) }\end{array}$ & 78.6 & 79.1 & -- & - \\
\hline 6.2 & $\begin{array}{l}\text { Number of new bank } \\
\text { branches opened }\end{array}$ & 7473 & 7213 & - & - \\
\hline 6.3 & $\begin{array}{l}\text { Number of villages } \\
\text { covered under Financial } \\
\text { Inclusion Plans (FIPs) }\end{array}$ & 181753 & 268454 & 56.4 & 48.0 \\
\hline
\end{tabular}

(Source: rbi.org.in) 
Dutta (2013) studied about determinants of return on assets of public sector bank. The study was based on backward multiple regression analysis to analyze the impact of determinants on the ROA of public sector banks. The variable Spread Ratio, OE, Provisions and Contingencies, NPA, NII is the significant determinants of ROA. The result of the study is that Spread and NII had positive influence and all other had negative impact. To improve the return on investment banks should focus on reducing their Operating bank should reduce operating expenses. Bapat (2013) studied about Growth, Profitability and Productivity in Public Sector Banks: An Assessment of Their Interrelationship. The study is conducted to measure the relationship among growth, profitability and productivity for Indian public sector banks. Business per employee, ROA, profit per employee is used to measure the same. The research methodology of study is ANOVA. The finding of study is growth rates do not significantly affect the profitability. Business per employee and profit per employee for Public sector banks remained higher for banks with higher growth rates. Gautam (2012) analyzed about how new technologies in banking have impacted on the profitability of the banks in India. With the availablity of internet, the retail banks are offering banking services to their customers through electronic medium i.e. e-banking. The study is qualitative in nature. It is based on the personal in-depth interviews of the bank managers of fourteen banks. The result suggests that electronic-banking has increased the profitability of banks, enabled the banks to meet their costs and earn profits even in the short run.The main motive of the banks to sport electronic-banking is to increase their clientele and to retain them. Balaji (2012) studied that how new financial products affect on profitability of Indian public sector bank. In study the research methodology is total 27 public sectors banks have been selected for to know the impact of new financial products on profitability of public sector banks. The period of the study is for 10 years i.e from 1999-00 to 2008-09. The period is divided into old financial products period from 1999-00 to 2004-05 and new financial products period from 2005-06 to 2008-09. After that he computed the data by calculating the trend percentage. The result of the study is public sector banks have less operating profit and net profit in old financial products period and during the new financial products have more operation and net profit amounts. Public sector banks have less expenditure amounts in old financial products period and during the new financial products have more expenditure amounts. Juneja et al (2012) studied about the profit earning and increasing the customer base the sole objective of all the bank groups. Keeping in view this competitive tendency of the banks, this study is mainly concentrated upon the comparison of different bank groups on their deposits, borrowings, loans and advances and investments related to different time periods. For the above analysis, all the banks are divided into four groups i.e. public sector banks, new private sector banks, old private sector banks and foreign banks. After the performance analysis, it is concluded that foreign banks are performing much better than the other bank groups, whereas the performance of old private sector banks is disappointing among all the bank groups. New private sector banks and Public sector banks are performing only satisfactorily. Guruswamy (2012) studied the determinants of profitability of SBI and Its Associates. The paper is primarily based on secondary data. To find the results, various statistical tools like mean, S.D, variance, CAGR, and ANOVA have been accomplished. The approach of policy makers towards profitability 
has changed, with the result that low profits have become a fact of life. Therefore, it is time to concentrate on analysis of the profitability performance. Sharma et al (2011) studied about Performance of Indian Public Sector Banks and Private Sector Banks: A Comparative Study how Indian banking industry has undergone radical changes due to liberalization and globalization measures undertaken since 1991. Increased competition, new information technologies and there by declining processing costs, the erosion of product and geographic boundaries, and less restrictive governmental regulations have all played a major role for Public Sector Banks in India to forcefully compete with Private and Foreign Banks. Dutta et al (2011) studied about the key determinants of profitability of Indian banks. The macroeconomic environment and industry level variables of India has been analyzed for estimating profitability of Indian banks. The findings of the paper are Credit Demand has an inverse relationship with bond yields on the other hand, has positive relationship with Gross Domestic Product. A higher economic activity increases loan demand. Deposit does not always lead to increase in credit supply growth Net interest income as well as efficiency ratio has significant role in determining profitability in Indian banking scenario. Kallurr (2009) studied about how the foreign banks entry in India affects the profitability of Indian bank. Due to foreign bank competition is increased. The increased competition seems to be deteriorating the loan quality evidenced by increasing default loans. Foreign bank entry also increases the overhead expenses of public banks. Basak et al (2008) studied about cooperative banks NPA and suggested that Co-operative banks should improve their recovery performance, adopt new system of computerized monitoring of loans, implement proper prudential norms and organize regular workshops to sustain in the competitive banking environment. Ketkar et al (2008) studied to examine the long run impact of reforms and liberalization on individual banks' efficiency and profitability. Regression analysisis used to explain efficiency differences among banks shows that the mandates on priority sector lending have hurt the efficiency of state-owned and nationalized banks but bank branch expansion mandates have not hurt their efficiency. The findings show that the relative efficiency of banks by ownership does not critically depend upon whether deposits are treated as an input (intermediation approach) or output (production approach). The efficnecy score has increased over the economic reforms and thus reflects the infusion of new capital and the increase in competition that these banks have experienced in recent years. Bodla et al (2007) studied about key determinants of profitability of public sector banks in India is identified. As per the study result importance of some variable like NII, OE, NPA, CD ratio is significantly high. Non-interest income, operating expenses, provision and contingencies and spread have a significant relationship with net profit. Kelkar et al (2006) studied to identified the key determinants of profitability of public sector banks in India. The analysis is based on step-wise multivariate regression model used on temporal data from 1991-92 to 2003-04. The study has brought out that the explanatory power of some variables is significantly high. Provision of better service quality, technology up gradation inculcating customer driven work culture, mental revolution among the staff of public sector banks, use of modern risk management practices are also the most sought after steps that are needed to ensure the sustainable level of profit and its growth. Nagarjuna et al (2006) studied about how performance of banking in terms of profitability, productivity, asset quality and financial management has become important to stable the economy. They found that public sector banks have been more efficient than other banks operating in India. Georgious et al 
(2005 studied that if the growth rate of sales of any bank is higher than the absolute growth rate of the bank's lending rate, the bank's profit will not decrease. Utaya (2005) studied about Profitability Analysis of the Pondicherry State Co-operative Bank. Various ratios, such as cost of management (total expenses) to working capital ratio, profit to working capital ratio, non-interest income to total income ratio, etc. were used to assess the general performance of the bank. Spread and burden positions of the bank were also analyzed. They concluded that the profitability performance of the bank was impressive and bank was able to meet its obligations and norms. The cost of management and establishment expenses got reduced during the period of study which further strengthened the profitability position of the bank. Ganesan (2001) studied about, "determinants of Profits and Profitability of public sector banks in India: A profit function approach" it examine the factors which showed that interest cost, interest income, other income, deposits per branch, credit to total assets. The study is based on the regression model .The result of study is significant determinants of profits and profitability of Indian public sector banks are interest income loss. The important note in paper was that the average establishment cost positively contributes to the profitability but it adversely affects the net profit of the public sector bank. Scholtens et al (2000) analyzed that there is an inverse relationship between the amount of bank capital, assets and profit and growth rate. To ensure long-term profitability in Shanghai, it is suggested that foreign banks need to contain costs and risks in new markets, identify appropriate customer target groups, formulate effective market penetration strategy, attract businesses from firms of different countries, seek early entry and undertake more fee income generating businesses.

\section{RESEARCH OBJECTIVE:}

- To determine the factors affecting profitability of PSBs in India.

\section{RESEARCH METHODOLOGY}

The variables have been selected on the basis of review of literature and subject to availability of data. Net profit (profit after tax) is dependent variable while independent variables are Net Non Performing Assets as percentage to net advances, Interest Income Spread, Credit/Deposit ratio and Operating expenses. The objectives of this study is to examine the impact of selected variables such as net interest income, nonperforming assets, credit-deposit ratio and operating expenses on the profitability of banks in India.

The time period of the study is from 2006 to 2013 i.e. 8 years, the data will be collected from the public sector banks (PSBs). Multiple Regression Model will be used for analysis and findings. 


\section{HYPOTHESIS:}

HO (1): There is no impact of net interest income on net profits of banks.

$\mathrm{Hl}$ (1): There is a significant impact of net interest income on net profits of banks.

HO (2): There is no impact of nonperforming assets on net profits of banks.

$\mathrm{Hl}$ (2): There is a significant impact of nonperforming assets on net profits of banks.

HO (3): There is no impact of credit-deposit ratio on net profits of banks.

$\mathrm{Hl}$ (3): There is a significant impact of credit-deposit ratio on net profits of banks.

HO (4): There is no impact of operating expenses on net profits of banks.

$\mathrm{Hl}$ (4): There is a significant impact of operating expenses on net profits of banks.

\section{MATHEMATICALLY EQUATION:}

$Y=a+b l x l+b 2 \times 2+b 3 \times 3+b 4 \times 4+e$

Where,

$\mathrm{Y}=$ Net Profit

$\mathrm{a}=$ constant term,

bl to b4 = Regression coefficients for the respective variables,

$\mathrm{Xl}=$ Net interest income

$\mathrm{X} 2=\mathrm{NPA}$ as percentage to Net Advances

$\mathrm{X} 3=$ Credit/Deposit Ratio (C/D)

$\mathrm{X} 4$ = Operating expenses

$\mathrm{e}=$ Error term

Here, Y (i.e. Net Profit) is the dependent variable, while the rest Xl to X4 are independent.

\section{ANALYTSIS OF DATA:}

TABLE 1: Correlations table

\begin{tabular}{|ll|r|r|r|r|r|}
\hline & Net Profit & NPA & $\begin{array}{c}\text { Net Interest } \\
\text { Income }\end{array}$ & $\begin{array}{c}\text { Credit } \\
\text { Deposit } \\
\text { Ratio }\end{array}$ & $\begin{array}{c}\text { Operating } \\
\text { Expenses }\end{array}$ \\
\hline NET PROFIT & Pearson & 1 & $-.560^{* *}$ & $.620^{* *}$ & $.639^{* *}$ & $.421^{* *}$ \\
& Sig. (2-tailed) & & .000 & .000 & .000 & .001 \\
$\mathrm{~N}$ & 40 & 40 & 40 & 40 & 40 \\
\hline $\mathrm{NPA}$ & Pearson & $-.560^{* *}$ & 1 & $-.512^{* *}$ & $-.799^{* *}$ & -.124 \\
& Correlation & .000 & & .001 & .000 & .001 \\
& Sig. (2-tailed) & 40 & 40 & 40 & 40 & 40 \\
\hline $\mathrm{N}$ & & & &
\end{tabular}




\begin{tabular}{|c|c|c|c|c|c|c|}
\hline $\begin{array}{l}\text { NET-INTEREST } \\
\text { INCOME }\end{array}$ & $\begin{array}{l}\text { Pearson } \\
\text { Correlation } \\
\text { Sig. (2-tailed) } \\
\mathrm{N}\end{array}$ & $\begin{array}{r}.620^{* *} \\
.000 \\
40\end{array}$ & $\begin{array}{r}-.512^{* *} \\
.001 \\
40\end{array}$ & 40 & $\begin{array}{r}.290 \\
.000 \\
40\end{array}$ & $\begin{array}{r}.454^{* *} \\
.000 \\
40\end{array}$ \\
\hline $\begin{array}{l}\text { CREDIT-DEPOSIT } \\
\text { RATIO }\end{array}$ & $\begin{array}{l}\text { Pearson } \\
\text { Correlation } \\
\text { Sig. (2-tailed) } \\
\mathrm{N}\end{array}$ & $\begin{array}{r}.639^{* *} \\
.000 \\
40\end{array}$ & $\begin{array}{r}-.799^{* *} \\
.000 \\
40\end{array}$ & $\begin{array}{r}.290 \\
.001 \\
40\end{array}$ & 40 & $\begin{array}{r}.336^{*} \\
.001 \\
40\end{array}$ \\
\hline OPERATING EXPENSES & $\begin{array}{l}\text { Pearson } \\
\text { Correlation } \\
\text { Sig. (2-tailed) } \\
\mathrm{N}\end{array}$ & $\begin{array}{r}.421^{* *} \\
.000 \\
40\end{array}$ & $\begin{array}{r}-.124 \\
.001 \\
40\end{array}$ & $\begin{array}{r}.454^{* *} \\
.000 \\
40\end{array}$ & $\begin{array}{r}.336^{*} \\
.000 \\
40\end{array}$ & 40 \\
\hline
\end{tabular}

**. Correlation is significant at the 0.01 level (2-tailed).

*. Correlation is significant at the 0.05 level (2-tailed).

\section{Interpretation:}

In all the cells, upper value shows the coefficient of correlation (r), the middle value represents the level of significance and the lower value represents the number of observations. The value of $r$ shows the degree of correlation between the variables. It can range from -1 to +1 . In the above table all the variables are correlated positively or negatively with each other.

The level of significance shows whether the variables are significantly correlated or not. As the level of significance increases, the accuracy level of correlation decreases. If the significance level is less than 0.05 , it means that the correlation between the variables is significant. In the above table all the variables are significantly correlated with each other as all the values are less than 0.05 .

From the above table the correlation between two variables has been observed as:

\begin{tabular}{|l|l|}
\hline Positive correlations & Negative correlations \\
\hline & Net profit and Non performing assets \\
\hline Net profit and Net interest income & Nonperforming assets and Net interest income \\
\hline Net profit and Credit Deposit ratio & Nonperforming assets and Operating expenses \\
\hline Net profit and operating expenses & Nonperforming assets and Credit Deposit ratio \\
\hline Credit Deposit ratio and Operating expenses & \\
\hline Net interest income and credit deposit ratio & \\
\hline Net interest income and operating expenses & \\
\hline credit deposit ratio and operating expenses & \\
\hline
\end{tabular}


TABLE 2: Model Summary

\begin{tabular}{|l|r|r|r|lr|}
\hline Model & $\mathrm{R}$ & $\begin{array}{c}\mathrm{R} \\
\text { Square }\end{array}$ & $\begin{array}{c}\text { Adjusted R } \\
\text { Square }\end{array}$ & \multicolumn{2}{|c|}{ Std. Error of the Estimate } \\
\hline $\mathrm{l}$ & $.802^{\mathrm{a}}$ & .643 & .602 & & 643.68865 \\
\hline
\end{tabular}

a. Predictors: (Constant), Operating expenses, NPA, Net interest income, Credit-Deposit ratio

- In the above table, the high value of $\mathrm{R}$ shows that independent variables predict dependent variable very well i.e. the variables net interest income, non performing assets, credit deposit ratio and operating expenses predict the net profits of the public sector banks very well.

- The range of $\mathrm{R}$ varies from 0 to 1 .

- In this model, the value of $\mathrm{R}$ square is 0.643 means that $64.3 \%$ of the total variation in Net Profit is explained by the variables Net Interest Income, Non Performing Assets, Credit Deposit Ratio and Operating Expenses. It means that by Knowing these independent variables Net Profit of Public Sector banks can be predicted.

- In this Study, the value of adjusted $\mathrm{R}$ square is 0.602 shows that the study has accounted for $60.2 \%$ of the variance in Net Profits.

TABLE 3: ANOVA

\begin{tabular}{|ll|r|r|r|r|rr|}
\hline Model & & \multicolumn{1}{c|}{$\begin{array}{c}\text { Sum of } \\
\text { Squares }\end{array}$} & Df & $\begin{array}{c}\text { Mean } \\
\text { Square }\end{array}$ & F & \multicolumn{2}{|c|}{ Sig. } \\
\hline 1 & Regression & $2.607 \mathrm{E} 7$ & 4 & 6517724.029 & 15.731 & & $.000^{\mathrm{a}}$ \\
& Residual & $1.450 \mathrm{E} 7$ & 35 & 414335.075 & & & \\
& Total & $4.057 \mathrm{E} 7$ & 39 & & & & \\
\hline
\end{tabular}

a. Predictors:(Constant), Operating Expenses, Nonperforming assets, Net interest income, Credit-deposit ratio

b. Dependent Variable: Net Profit

In this Study, F value was used for testing the Hypotheses. Since the level of significance is less than 0.05 , therefore Null hypotheses may be rejected and Alternative hypotheses accepted. It means that there is significant impact of at least one independent variables on Net Profits of banks. 
TABLE 4: Variables Entered/Removed ${ }^{\mathrm{b}}$

\begin{tabular}{|l|l|l|l|}
\hline Model & Variables Entered & Variables Removed & Method \\
\hline 1 & $\begin{array}{l}\text { Operating expenses, NPA, Net } \\
\text { Interest income, Credit- } \\
\text { deposit ratio }\end{array}$ & & Enter \\
\hline
\end{tabular}

a. All requested variables entered.

b. Dependent Variable: Net Profit

\section{TABLE 5:Coefficients ${ }^{\mathrm{a}}$}

\begin{tabular}{|c|c|c|c|c|c|c|c|c|}
\hline \multirow{2}{*}{\multicolumn{2}{|c|}{ Model }} & \multicolumn{2}{|c|}{$\begin{array}{c}\text { Unstandardized } \\
\text { Coefficients }\end{array}$} & \multirow{2}{*}{\begin{tabular}{|c}
$\begin{array}{c}\text { Standardiz } \\
\text { ed } \\
\text { Coefficient } \\
\mathrm{s}\end{array}$ \\
Beta
\end{tabular}} & \multirow[b]{2}{*}{$t$} & \multirow[b]{2}{*}{ Sig. } & \multicolumn{2}{|c|}{ Collinearity Statistics } \\
\hline & & B & Std. Error & & & & $\begin{array}{c}\text { Toleranc } \\
\mathrm{e}\end{array}$ & VIF \\
\hline \multirow[t]{5}{*}{1} & (Constant) & -235.462 & 170.995 & & -1.377 & .177 & & \\
\hline & NPA & .001 & .001 & .375 & 1.614 & .116 & .189 & 5.25 \\
\hline & INTEREST INCOME & .135 & .033 & .620 & 4.031 & .000 & .432 & 2.31 \\
\hline & $\begin{array}{l}\text { CREDIT-DEPOSIT } \\
\text { RATIO }\end{array}$ & 77.529 & 20.993 & .785 & 3.693 & .001 & .226 & 4.4 \\
\hline & $\begin{array}{l}\text { OPERATING } \\
\text { EXPENSES }\end{array}$ & -.057 & .103 & -.078 & -.552 & .585 & .514 & 1.945 \\
\hline
\end{tabular}

a. Dependent Variable: Net Profit

Interpretation: The above table represents the beta value of interest income (.620) and credit deposit ratio (.785) is more than other two variable, NPA (.375) and operating expenses (.078) so here interest income and credit deposit ratio having more impact on net profit of the bank. Further more for the test of colllinearity, VIF value should be more than 10 but in our study it is less than 10 it means there is a negligible relation between independent variable. 
So we have not considered backward selection method of regression and have not used Durbin Weston test to remove any variable. Because VIF is less than 10 so there is no relation exist between the independent variable.

\section{CONCLUSION:}

An attempt has been made to identify the key determinants of profitability of top five public sector banks in India. The study has brought out that the explanatory power of some variables is significantly high. Such variables are credit deposit ratio and interest income. However, some variables namely operating expenses and non-performing assets are found with low explanatory power. Hence, the variables credit-deposit ratio and interest income have a significant relationship with net profit. The net profits of public sector banks have significantly correlation with net interest income, non-performing assets, credit-deposit ratio and operating expenses. The independent variables very well predict the net profit of public sector banks. Approximately $60.2 \%$ of the total variation in net profit is explained by the variables net interest income, non-performing assets, credit-deposit ratio and operating expenses. Credit Deposit ratio has the largest effect on net profits and operating expenses having the least impact on net profits.

\section{$\underline{\text { References: }}$}

Dutta, S., Gupta, N., \& Rao, P. H. (2013). Determinants of Return on Assets of Public Sector Banks in India: An Empirical study. Pacific Business Review International , 5 (11), 23-28.

Bapat, D. (2013). Growth, Profitability and Productivity in Public Sector Banks:. The IUP Journal of Bank Management , 12, 50-57.

Balaji, C., \& Kumar, G. P. (2012). Impact New Financial Products On Profitability of Public Sector banks inIndia,.Internationl journal of management research , 2 (5), 783-791.

Guruswamy, D. D. (2012). Analysis of profitability performance of SBI and its associates banks. International Journal of Business Economics \& Management Research , 2, 105-125.

Gautam, V. (2012). Measuring the Impact of New Technologies through Electronic-Banking on Profitability of Banks: Evidence form Indian Banking Industry.

Mahajan, P., \& Chander, S. (2012). ROA Performance of Public Sector Banks in India. The IUP Journal of Bank Management , 12, 22-35.

Malhotra, ,. D., \& Poteau, R. (2011). Evaluating the performance of commercial banks in india .Asia Pacific Journal of Finance and Banking Research , 5, 15-37.

Chaudhary, K., \& Sharma, M. (2011). Performance of Indian Public Sector Banks and Private sector banks. International Journal of Innovation, Management and Technology , 2 (3), 249-256

Kumar, S., \& Gulati, R. (2010). Measuring efficiency, effectiveness and performance, of Indian public sector banks. International Journal of Productivity and Performance Management, 59, 51-74. 
Sathya, D. S., \& Shil, N. C. (2009). Key Discriminators of Bank Profitability. Interdisiplinary Journal of Contemporary Research in Business , 1 (2), 97-110.

Bodla, B. S., \& Varma, R. (2007). Determinants of profitability of banks in India: A maltivarite analysis. Journal of Services Research , 6, 75-89.

Kalluru, s., \& Bhutt, S. K. (2007). Does Foreign Bank Entry Affect Operations of Domestic Banks. Department of Economics, Pondicherry Central University,, Pondicherry.

Badola, B. S., \& Verma, R. (2006). Determinants of profitability of banks in india. Delhi Business Review , 7 (2), 79-88.

Abdallah, A. M. (2006). Evaluate the Profitability in Commercial Bank in india. Asian Journal of Finance e Accounting , 5 (1).

Suryan K.Uthaya, a. V. (2005). "Profitability Analysis of the Pondicherry State Co-operative Bank",. NAFSCOB Bulletin, (April), Mumbai.

Wilson, J. A. (2004). "The Profitability of European Banks: A Cross-Sectional and Dynamic Panel Analysis,”. Manchester School, , Vol.72, No.3, pp 363-381.

Koeva, P. (2003). The performance of indian banks during financial liberlization. IMF working paper, $1-33$.

Ram Mohan, T. T. (2002). "Deregulation and Performance of Public Sector Banks". Economic and Political Weekly, Special Issue on Money, Banking and Finance, , 393-9

Ganesan, P. (2001, june). Determinants of profits and profitability of public sector banks in India: A profit function approac. Journal of Financial Management $\mathrm{O}$ Analysis , 27-37.

\section{Webliography}

https://ibef.org

https://www.rbi.org.in

https://www.moneycontrol.com

https://www.capitaline.com

https://www.sbi.co.in

http://www.bankofbaroda.co.in

https://www.pnbindia.in

http://www.canarabank.in/

http://www.bankofindia.co.in/

The journal is a scholarly peer reviewed and refereed publication and is a publisher member of PILA Inc., USA. (CrossRef). (C) Institute of Research Advances. Website: http://www.research-advances.org/journal/ 
DATA:

Punjab National Bank data of 10 years Mar 04 to Mar 13) In Cr

Net Gross Int C-D

$\begin{array}{lllllllllll}\text { Year } & \text { profit } & \text { Change } & \text { NPA } & \text { Change } & \text { income } & \text { Change } & \text { Ratio } & \text { Change } & \text { O-E } & \text { Change } \\ 2013 & 4747.67 & -136.53 & 134657 & 47461 & 41893.33 & 5465.3 & 78.89 & -0.2 & 8165.1 & 1162.3 \\ 2012 & 4884.2 & 450.7 & 87196 & -350743 & 36428.03 & 9441.6 & 79.09 & 2.2 & 7002.8 & 638.53 \\ 2011 & 4433.5 & 528.14 & 437939 & 116498 & 26986.48 & 5519.6 & 76.89 & 1.31 & 6364.2 & 602.86 \\ 2010 & 3905.36 & 814.48 & 321441 & 44695 & 21466.91 & 2140.8 & 75.58 & -0.48 & 5761.4 & 734.55 \\ 2009 & 3090.88 & 1042.12 & 276746 & -55184 & 19326.16 & 5061.1 & 76.06 & -0.39 & 5026.8 & 1124.26 \\ 2008 & 2048.76 & 508.68 & 331930 & -7142 & 14265.02 & 2727.5 & 76.45 & 2.11 & 3902.6 & -23.5 \\ 2007 & 1540.08 & 100.77 & 339072 & 25243 & 11537.48 & 1953.3 & 74.34 & 6.3 & 3926.1 & 662.9 \\ 2006 & 1439.31 & \text { \#REF! } & 313829 & \text { \#REF! } & 9584.15 & \text { \#REF! } & 68.04 & \text { \#REF! } & 3263.2 & \text { \#REF! }\end{array}$

Bank of Baroda data of 10 years Mar 04 to Mar 13) in Cr

\begin{tabular}{lllllllllll} 
& Net & \multicolumn{3}{c}{ Gross } & \multicolumn{9}{c}{ Int } & C-D \\
Year & profit & Change & NPA & Change & income & Change & Ratio & Change & O-E & Change \\
2013 & 4480.72 & -526.24 & 79825.8 & 35177.8 & 35196.65 & 5522.9 & 69.25 & -5.42 & 5946.7 & 5522.93 \\
& & & & - & & & & & & \\
2012 & 5006.96 & 765.28 & 44648 & 270602 & 29673.72 & 7787.8 & 74.67 & -0.2 & 5158.7 & 7787.8 \\
2011 & 4241.68 & 1183.35 & 315250 & 75181 & 21885.92 & 5187.6 & 74.87 & 1.27 & 4629.8 & 5187.58 \\
2010 & 3058.33 & 831.13 & 240069 & 55776.4 & 16698.34 & 1606.8 & 73.6 & 0.82 & 4711.2 & 1606.76 \\
2009 & 2227.2 & 791.68 & 184292.57 & -13845 & 15091.58 & 3278.1 & 72.78 & 4.06 & 3844.7 & 3278.1 \\
2008 & 1435.52 & 409.06 & 198138 & -11076 & 11813.48 & 2600.8 & 68.72 & 3.05 & 3370.3 & 2600.84 \\
2007 & 1026.46 & -23.61 & 209214 & -29800 & 9212.64 & 2112.6 & 65.67 & 6.63 & 2771.5 & 2112.64 \\
2006 & 1050.07 & 1050.07 & 239014 & 239014 & 7100 & 7100 & 59.04 & 59.04 & 2724.8 & 7100
\end{tabular}

Bank of India data of 10 years Mar 04 to Mar 13) in Cr

$\begin{array}{lllllllllll}\text { Year } & \begin{array}{l}\text { Net } \\ \text { profit }\end{array} & \begin{array}{l}\text { Change } \\ \text { 2013 }\end{array} & \text { NPA } & \text { Change } & \text { income } & \text { Change } & \text { Ratio } & \text { Change } & \text { O-E } & \text { Change } \\ & 2741.19 & 66.57 & 93095.3 & 28386.3 & 31908.93 & 3428.3 & 75.78 & 0.93 & 5455.9 & 3428.26 \\ 2012 & 2674.62 & 185.91 & 64709 & 416446 & 28480.67 & 6729 & 74.85 & 2.67 & 7036.6 & 6728.95 \\ 2011 & 2488.71 & 750.15 & 481155 & -7110 & 21751.72 & 3873.7 & 72.18 & -2.06 & 6179.4 & 3873.73 \\ 2010 & 1738.56 & -1270.9 & 488265 & 241177 & 17877.99 & 1530.6 & 74.24 & -1.23 & 5474 & 1530.63 \\ 2009 & 3009.41 & 1049.13 & 247088 & 53996 & 16347.36 & 3992.1 & 75.47 & 1.96 & 3767.5 & 3992.14 \\ 2008 & 1960.28 & 834.33 & 193092 & -16957 & 12355.22 & 3174.9 & 73.51 & 3.3 & 3420.1 & 3174.89 \\ 2007 & 1125.95 & 422.37 & 210049 & -37869 & 9180.33 & 2151.6 & 70.21 & 0.06 & 3139 & 2151.63 \\ 2006 & 703.58 & \text { \#REF! } & 247918 & \text { \#REF! } & 7028.7 & \text { \#REF! } & 70.15 & \text { \#REF! } & 2654.1 & \text { \#REF! }\end{array}$


Canara Bank data of 10 years Mar 04 to Mar 13) In Cr

\begin{tabular}{|c|c|c|c|c|c|c|c|c|c|c|}
\hline & Net & & Gross & & Int & & C-D & & & \\
\hline Year & profit & Change & NPA & Change & income & Change & Ratio & Change & $\mathrm{O}-\mathrm{E}$ & Change \\
\hline \multirow[t]{2}{*}{2013} & 3282.71 & -743.18 & 62601.6 & 22283.6 & 30850.62 & 7786.6 & 71.65 & -0.58 & 5967.8 & 7786.61 \\
\hline & & & & - & & & & & & \\
\hline 2012 & 4025.89 & 1004.46 & 40318 & 268603 & 23064.01 & 4312.1 & 72.23 & -0.73 & 5420.5 & 4312.05 \\
\hline 2011 & 3021.43 & 949.01 & 308921 & 49890 & 18751.96 & 1632.9 & 72.96 & 0.97 & 4903.8 & 1632.91 \\
\hline 2010 & 2072.42 & 507.41 & 259031 & 42234 & 17119.05 & 2918.3 & 71.99 & 2.59 & 3965.2 & 2918.31 \\
\hline 2009 & 1565.01 & 144.2 & 216797 & 75242 & 14200.74 & 2836.2 & 69.4 & 0.75 & 3666.3 & 2836.18 \\
\hline 2008 & 1420.81 & 77.59 & 141555 & -7788 & 11364.56 & 2653.1 & 68.65 & 3.21 & 3023.3 & 2653.05 \\
\hline 2007 & 1343.22 & 233.72 & 149343 & -29918 & 8711.51 & 1139.5 & 65.44 & 6.47 & 2982.3 & 1139.54 \\
\hline 2006 & 1109.5 & & 179261 & & 7571.97 & & 58.97 & & 2915.9 & \\
\hline
\end{tabular}

State Bank of India data of 10 years Mar 04 to Mar 13) In Cr

\begin{tabular}{lllllllllll} 
& Net & \multicolumn{3}{c}{ Gross } & \multicolumn{3}{c}{ Int } & C-D & & \\
YEARS & profit & Change & NPA & Change & income & Change & Ratio & Change & O-E & Change \\
2013 & 14104.98 & 2397.69 & 511893.9 & 115129 & 119657.1 & 13136 & 86.94 & 3.81 & 29284 & 13135.65 \\
2012 & 11707.29 & 4336.94 & 396765 & $-2 \mathrm{E}+06$ & 106521.45 & 25127 & 83.13 & 46.77 & 26069 & 25127.09 \\
2011 & 7370.35 & -1795.7 & 2532629 & 579140 & 81394.36 & 10400 & 36.36 & -39.6 & 23015 & 10400.44 \\
2010 & 9166.05 & 44.82 & 1953489 & 318925 & 70993.92 & 7205.5 & 75.96 & 0.99 & 24941 & 7205.49 \\
2009 & 9121.23 & 2392.11 & 1634564 & 350830 & 63788.43 & 14838 & 74.97 & -2.54 & 18124 & 14838.12 \\
2008 & 6729.12 & 2187.81 & 1283734 & 283912 & 48950.31 & 9459.3 & 77.51 & 4.07 & 14610 & 9459.28 \\
2007 & 4541.31 & 134.64 & 999822 & -37754 & 39491.03 & 3696.1 & 73.44 & 11.33 & 13252 & 3696.1 \\
2006 & 4406.67 & 4406.67 & 1037576 & 1037576 & 35794.93 & 35795 & 62.11 & 62.11 & 11873 & 35794.93
\end{tabular}

Note:

O-E (Operating Expenses)

Int (Interest)

C-D Ratio (Credit Deposit Ratio)

Change (Change over the period) 